\title{
KAJIAN EKOLOGIS SUNGAI ARBES AMBON MALUKU
}

\author{
Nirmala Fitria Firdhausi ${ }^{1}$, Muhammad Rijal ${ }^{2}$, Hasni Yati Husen ${ }^{3}$ \\ 1,2,3 Program Studi Pendidikan Biologi IAIN Ambon
}

\begin{abstract}
Abstrak: Keanekaragaman jenis adalah keanekaragaman yang ditemukan di antara makhluk hidup yang berbeda jenis di dalam sebuah ekosistem, baik tumbuhan, hewan, dan mikroorganisme. Ada beragam jenis ekosistem yang dapat dijumpai di bumi ini. Semua ekosistem tersebut akan membentuk satu kesatuan yang disebut dengan Biosfer. Salah satu ekosistem yang mudah untuk tercemari adalah ekosistem Sungai. Berdasarkan hasil penelitian yang telah dilakukan di kawasan DAS sungai Air Besar Batu Merah Ambon, ditemukan 5 spesies capung jarum yang tergolong dalam 3 family capung jarum (Zygoptera) dan total jumlah individu pada ketiga stasiun yaitu 51 individu. Berdasarkan hasil penelitian hanya ditemukan dua spesies gastropoda yaitu Pupina bilobata dan Ena Montana. Penghitungan nilai Familli Biotik Indeks hanya mencakup 4 familly yaitu Cordullidae, Gerridae, Hirudinidae, Tricoptera. Dimana hanya keempat family tersebut yang tergolong dalam makroinvertebrata indikator yang sensitif terhadap polutan. Nilai FBI menunjukkan kondisi perairan pada stasiun 1 tergolong sangat baik. Begitu pula dengan kondisi perairan pada stasiun II dimana nilai FBI diantara 0-3.75 yang berarti sangat baik.
\end{abstract}

\section{Kata Kunci: Keanekaragaman, Ekosistem, Sungai Arbes, FBI}

Ekosistem akuatik adalah tipe ekosistem yang sebagai lingkungan fisiknya didominasi oleh air. Ekosistem akuatik dipengaruhi oleh empat faktor yaitu penetrasi cahaya matahari, substrat, temperatur dan jumlah material terlarut. Akan tetapi, faktor penentu utama dari ekosistem perairan adalah jumlah garam terlarut di dalam air. jika mengandung kadar garam yang tinggi, maka disebut ekosistem laut Sebaliknya, Jika perairan tersebut sedikit mengandung garam terlarut maka disebut ekosistem air tawar (Anonim, 2017).

Sungai merupakan badan air yang berbentuk memanjang pada permukaan bumi yang terbentuk secara alamiah, mulai dari yang berukuran kecil di bagian hulu, sampai ukuran besar bagian hilir. Fungsi sungai yaitu, untuk menampung air hujan yang jatuh diatas permukaan bumi dan mengalirkanya beserta material yang ada di dalamnya ketempat-tempat yang lebih rendah dan terus mengalir ke laut (Leobis dkk, 2013). Sungai sebagai salah satu badan perairan sangat dipengaruhi oleh banyak faktor, baik faktor alam maupun aktivitas manusia. Adanya masukan limbah atau sampah dari kegiatan manusia di sekitar badan sungai secara langsung atau tidak langsung dapat mempengaruhi kondisi fisika dan kimia air sungai, yang akhirnya dapat mempengaruhi kehidupan biota di dalam maupun di sekitar sungai tersebut.

BIOLOGI SEL (VOL 7 NO 1 EDISI JAN-JUL 2018 ISSN 2252-858X/E-ISSN 2541-1225) PAGE 13 
Sungai Arbes merupakan salah satu sungai yang terletak di Kecamatan Sirimau Desa Batu Merah Ambon. Sungai Arbes banyak dimanfaatkan oleh masyarakat yang berada di sekitar sungai untuk memenuhi kebutuhan hidup sehari-hari. Selain itu, digunakan juga sebagai tempat pembuangan sampah dan air limbah domestik, baik secara langsung maupun tidak langsung. Pemanfaatan sungai yang dilakukan oleh masyarakat tersebut dapat menyebabkan terjadinya pencemaran air sungai.

Pemantauan kondisi sungai dapat dilakukan dengan memperhatikan biota yang hidupdi dalamdan sekitarnya. Beberapadiantaranya adalah makrobentos dan capung. Capung memiliki peranan penting bagi manusia yaitu sebagai indikator untuk memantau kualitas air di sekitar lingkungan hidup. Nimfa capung tidak akan hidup pada air yang tercemar atau yang tidak bervegetasi. Nimfa capung memangsa seranggaserangga kecil lain yang hidup di dalam air. Nimfa capung dapat menampung polutan bersifat racun yang berasal dari mangsanya. Kenyataan ini bisa diartikan bahwa kelangsungan hidup capung dapat di gunakan sebagai bioindikator lingkungan aquatic (Waston, 2013). Makrobentos dapat digunkan sebagai bioindikator karena hidup melekat pada substrat dan motilitasnya rendah sehingga dia tidak mudah bergerak berpindah (Chay Asdak,2010).

\section{METODE PENELITIAN}

\section{Pengambilan Sampel Capung}

Lokasi pengambilan sampel dilakukan di kawasan DAS sungai Arbes Batu Merah Ambon. Adapun lokasi yang dijadikan sebagai titik stasiun yaitu: di lokasi sekitar hulu sungai Arbes Batu Merah Ambon, di lokasi sekitar pertengahan sungai Arbes Batu Merah Ambon dan di lokasi hilir sungai Arbes Batu Merah Ambon. Teknik pengambilan sampel dilakukan dengan teknik purposive sampling. Yaitu pengambilan sampel dilakukan pada lokasi yang terpilih sepanjang penelitian, sampling bersifat purposive yaitu tergantung pada tujuan fokus (Anonim, 2014). Sedangkan pengambilan data dilakukan dengan menggunakan metode jelajah (field by field method).

Capung ditangkap menggunakan jaring-jaring (sweep net) berbentuk kerucut dengan tinggi $60 \mathrm{~cm}$, diameter 300-380 cm, dan panjang tongkat jaring 1 meter. Dalam sekali tangkap terdiri dari 6 kali ayunan, penangkapan dilakukan mulai pukul 09.0012.00 WIT, hal ini dilakukan karena capung termasuk dalam golongan serangga yang aktif pada siang hari. Capung yang di dapat dimasukkan kedalam toples yang berisi kapas yang telah dibasahi oleh alkohol $70 \%$ atau clorofom. Capung tersebut dibawa ke laboratorium untuk di identifikasi dan dikeringkan serta disuntikkan dengan formalin $2 \%$ untuk diawetkan, diberi nama kolektor pada setiap capung yang didapatkan kemudian dicocokan dengan buku identifikasi capung (kunci determinasi serangga), kemudian dikelompokkan, difoto dan dibuat deskripsinya.(Sri Suharmi,1991). Dihitung jumlah individu, dan spesies, data ditampilkan dalam bentuk Tabel.

BIOLOGI SEL (VOL 7 NO 1 EDISI JAN-JUL 2018 ISSN 2252-858X/E-ISSN 2541-1225) PAGE 14 


\section{Pengambilan Sampel Makrobentos}

Lokasi pengambilan sampel makrobentos sama dengan lokasi pengambilan sampel capung akan tetapi untuk makrobentos pada badan sungainya. Pada setiap stasiun dilakukan pengambilan sampel sebanyak 3 titik pada bagian kanan, kiri dan tengah badan sungai.

Sampling dilakukan pada setiap stasiun dengan teknik mengaduk dengan kaki (kick methode) pada bagian berbatu dan berarus deras dan teknik menyapu dengan jarring (sweep methode) pada bagian tepi sungai diantara tumbuhan air. Pengambilan sampel dilakukan ditengah, di sisi kanan dan kiri sungai. Sampel yang telah diambil kemudian dimasukkan ke dalam bungkus E-tik kemudian mengidentifikasi biota sampai tingkat family. Penentuan jenis dilakukan dengan bantuan buku identifikasi gastropoda (Robert dan Soemadiharga, 1982). Identifikasi sampel dilakukan langsung di tempat penelitian. Sampel gastropoda di masukkan ke dalam plastik $e$-tik dengan penambahan alkohol $70 \%$.

\section{HASIL DAN PEMBAHASAN}

\section{Keanekaragaman Jenis Capung}

Berdasarkan hasil penelitian yang telah dilakukan di kawasan DAS sungai Air Besar Batu Merah Ambon, ditemukan 5 spesies capung jarum yang tergolong dalam 3 family capung jarum (Zygoptera) dan total jumlah individu pada ketiga stasiun yaitu 51 individu yang dapat kita lihat pada Tabel dibawah ini.

Tabel 1. Spesies capung jarum yang ditemukan pada ke tiga stasiun yang menjadi titik pengamatan dapat dilihat pada tabel berikut ini:

\begin{tabular}{|c|c|c|c|c|}
\hline No & Stasiun & No & Spesies & $\begin{array}{c}\text { Jumlah } \\
\text { Individu }\end{array}$ \\
\hline \multirow{5}{*}{1.} & \multirow{5}{*}{ Daerah Hulu sungai } & 1. & Ischnura senegalensis & 5 \\
\hline & & 2. & Ischnura heterosticta & 13 \\
\hline & & 3. & Agriocnemis femina & 7 \\
\hline & & 4. & Prodasineura autumnalis & 8 \\
\hline & & 5. & Coeliccia membranipes & 2 \\
\hline \multicolumn{4}{|c|}{ Total Individu } & 35 \\
\hline \multirow{2}{*}{2.} & \multirow{2}{*}{ Daerah Tengah sungai } & 1. & Ischnura heterosticta & 7 \\
\hline & & 2. & Prodasineura autumnalis & 4 \\
\hline \multicolumn{4}{|c|}{ Total Individu } & 11 \\
\hline 3. & Daerah Hilir sungai & 1. & Ischnura Heterosticta & 5 \\
\hline \multicolumn{4}{|c|}{ Total Individu } & 5 \\
\hline
\end{tabular}




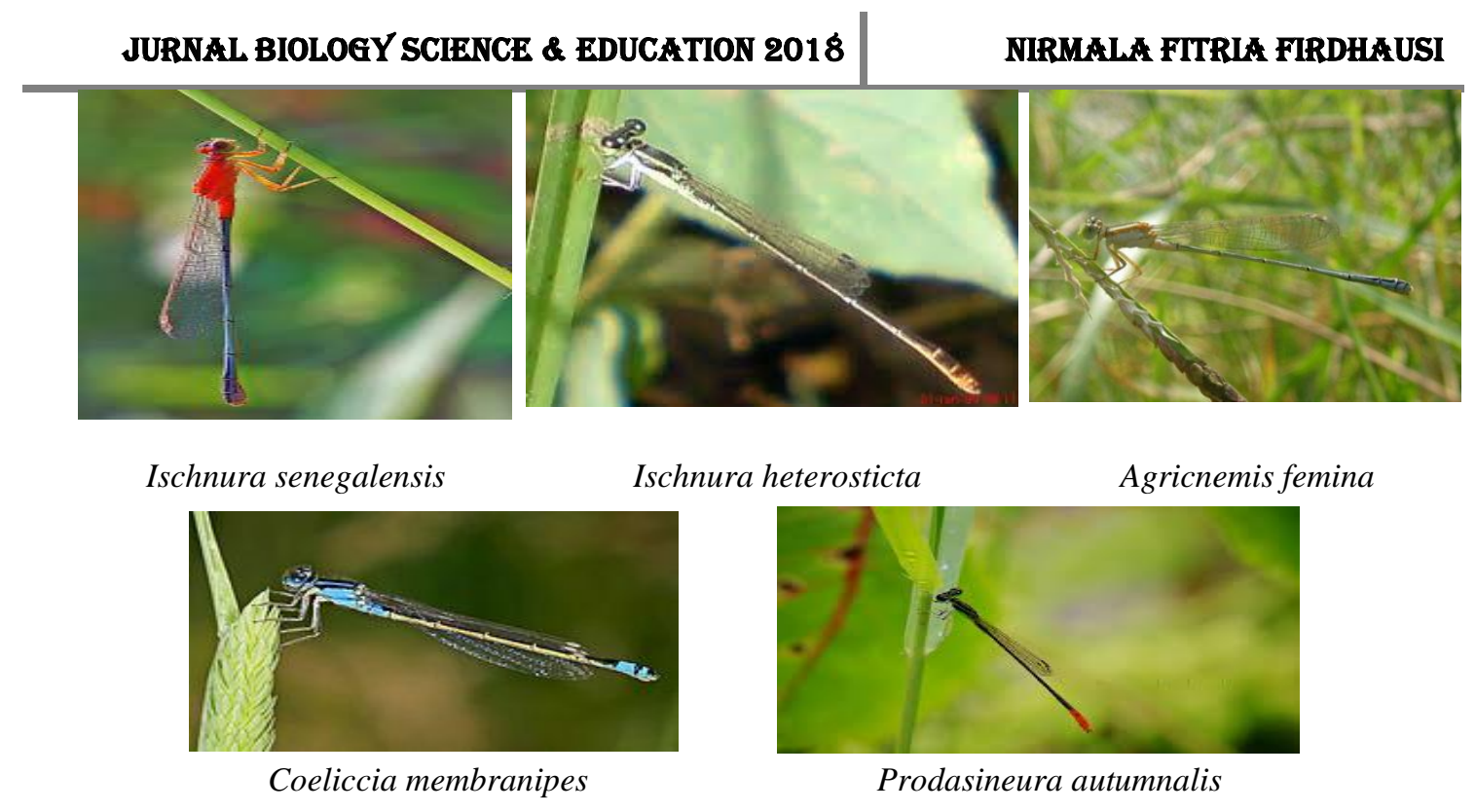

Berdasarkan indeks Shanon wiener keanekaragaman capung jarum (Zygoptera) di sekitar DAS Arbes adalah sebagai berikut:

Tabel 2. Nilai Indeks Keragaman Capung pada masing-masing Stasiun Di Kawasan DAS Sungai Arbes Batu Merah Ambon

\begin{tabular}{|c|c|c|c|}
\hline No & Stasiun & H' & Keragaman \\
\hline 1. & I (Hulu) & 1,415 & Keragaman rendah \\
\hline 2. & II (Tengah) & 0,654 & Keragaman rendah \\
\hline 3. & III (Hilir) & 0 & Keragaman rendah \\
\hline
\end{tabular}

Sedangkan capung sub ordo Anisoptera yang semuanya tergolong dalam famili Libellulidae dapat kita lihat pada tabel dibawah ini.

Tabel 3. Spesies dan Family Capung Sub Ordo Anisoptera yang ada Di Sekitar DAS Arbes Batu Merah Ambon beserta Jumlah Individu yang Didapatkan.

\begin{tabular}{|c|c|c|c|c|c|}
\hline \multirow{2}{*}{ No } & \multirow{2}{*}{ Spesies } & \multirow{2}{*}{ Familli } & \multicolumn{3}{|c|}{ Jumlah individu tiap stasiun } \\
\hline & & & I & II & III \\
\hline 1. & Neurorhemis terminata $\hat{\sigma}$ & Libellulidae & 7 & 8 & - \\
\hline 2. & Neurothemis terminata $q_{+}$ & Libellulidae & 4 & 2 & - \\
\hline 3. & Orthetrum Sabina & Libellulidae & 6 & 7 & 2 \\
\hline 4. & 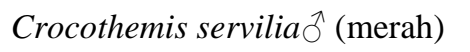 & Libellulidae & - & 3 & - \\
\hline 5. & Crocothemis servilia + (kuning) & Libellulidae & - & 17 & - \\
\hline 6. & Rhyothemis Phyllis & Libellulidae & - & 1 & - \\
\hline 7. & Libellula cyanea & Libellulidae & 12 & - & 3 \\
\hline \multirow[t]{3}{*}{8.} & Brachytemis contaminate & Libellulidae & 4 & 1 & - \\
\hline & \multicolumn{2}{|c|}{ Total } & 33 & 39 & 5 \\
\hline & \multicolumn{2}{|c|}{ Jumlah seluruh individu } & \multicolumn{3}{|c|}{77} \\
\hline
\end{tabular}




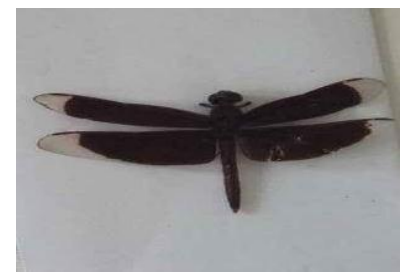

Neurothemis terminata $\hat{\jmath}(\mathrm{jantan})$

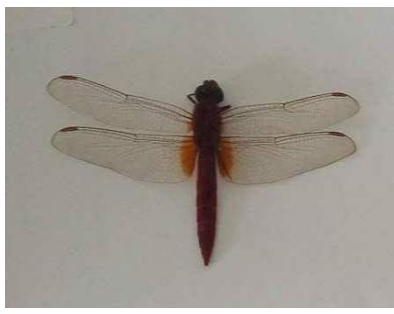

Crocothemis servilia

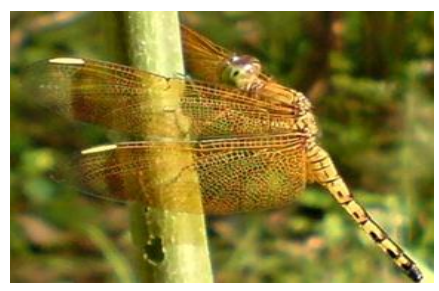

Neurothemis terminata + (betina)

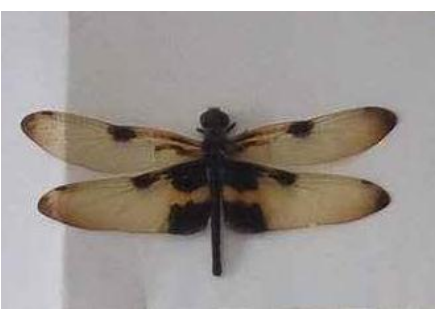

Rhyothemis phyllis

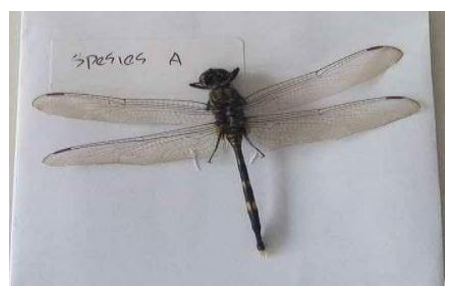

Orthetrum sabina

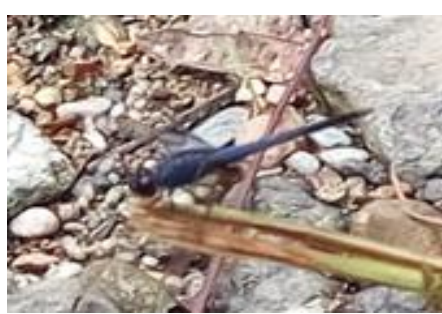

Libellula cyanea

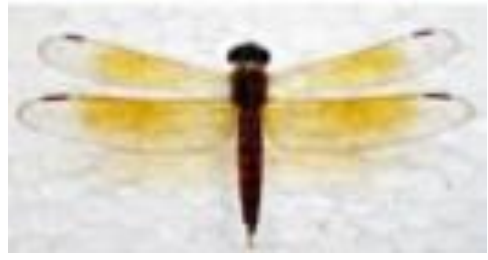

Brachytemis contaminata

Berdasarkan indeks Shanon wiener keanekaragaman capung (Anisoptera) di sekitar DAS Arbes adalah sebagai berikut:

Tabel 4. Nilai Indeks Keragaman Capung sub ordo Anisoptera pada masing-masing stasiun

\begin{tabular}{|c|c|c|c|}
\hline No & Stasiun & H'$^{\prime}$ & Keragaman \\
\hline 1. & I & 1,514 & Keragaman sedang \\
\hline 2. & II & 1,526 & Keragaman sedang \\
\hline 3. & III & 0,672 & Keragaman rendah \\
\hline
\end{tabular}

\section{Keanekaragaman Jenis Makrobentos}

Hasil identifikasi terhadap gastropoda yang ditemukan pada sungai Arbes dapat di lihat pada table 5 (Robert dan Soemadiharga, 1982). Berdasarkan hasil penelitian hanya ditemukan dua spesies gastropoda yaitu Pupina bilobata dan Ena montana.

Tabel 5. Jumlah Jenis Gastropoda yang didapatkan di Sungai Arbes pada ketiga stasiun (individu)

\begin{tabular}{|c|c|c|c|c|c|c|c|}
\hline \multirow{2}{*}{ Lokasi } & \multirow{2}{*}{ Stasiun } & & \multirow{2}{*}{ Jenis } & \multicolumn{3}{|c|}{ Jumlah yang di dapat } & \multirow{2}{*}{ Jumlah } \\
\hline & & & & Kiri & Tengah & Kanan & \\
\hline \multirow{5}{*}{ Arbes (Hulu) } & \multirow{5}{*}{ I } & \multirow{2}{*}{1} & Pupina bilobata & 1 & 3 & - & 4 \\
\hline & & & Ena Montana & - & - & - & 0 \\
\hline & & \multirow{2}{*}{2} & Pupina bilobata & 18 & 2 & - & 20 \\
\hline & & & Ena Montana & 1 & - & 3 & 4 \\
\hline & & 3 & Pupina bilobata & 1 & 8 & 2 & 11 \\
\hline
\end{tabular}

BIOLOGI SEL (VOL 7 NO 1 EDISI JAN-JUL 2018 ISSN 2252-858X/E-ISSN 2541-1225) PAGE 17 


\begin{tabular}{|c|c|c|c|c|c|c|c|}
\hline & & & Ena Montana & 11 & - & 1 & 12 \\
\hline \multirow{6}{*}{$\begin{array}{c}\text { Wara } \\
\text { (Tengah) }\end{array}$} & \multirow{6}{*}{ II } & \multirow{2}{*}{1} & Pupina bilobata & 9 & 3 & 1 & 13 \\
\hline & & & Ena Montana & 2 & - & 12 & 14 \\
\hline & & \multirow{2}{*}{2} & Pupina bilobata & - & - & 3 & 3 \\
\hline & & & Ena Montana & 4 & - & 12 & 16 \\
\hline & & \multirow{2}{*}{3} & Pupina bilobata & 5 & 2 & 1 & 8 \\
\hline & & & Ena Montana & - & 1 & 420 & 421 \\
\hline \multirow{6}{*}{$\begin{array}{l}\text { Galala } \\
\text { (Hilir) }\end{array}$} & \multirow{6}{*}{ III } & \multirow[t]{2}{*}{1} & Pupina bilobata & - & - & 2 & 0 \\
\hline & & & Ena Montana & 62 & 26 & 172 & 260 \\
\hline & & \multirow{2}{*}{2} & Pupina bilobata & - & - & - & - \\
\hline & & & Ena Montana & 493 & 33 & 521 & 1,047 \\
\hline & & \multirow{2}{*}{3} & Pupina bilobata & - & - & - & - \\
\hline & & & Ena Montana & 203 & 17 & 192 & 412 \\
\hline
\end{tabular}

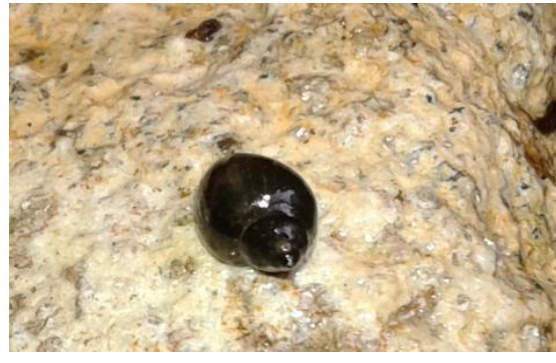

Pupina bilobata

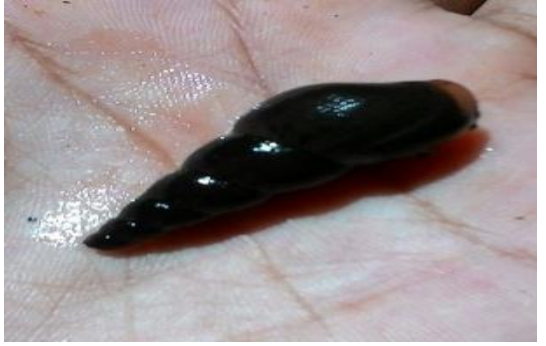

Ena Montana

Table 6 .Nilai Indeks keanekaragaman Gastropoda dan (H') di Tiga Sungai Arbes.

\begin{tabular}{|c|c|c|c|c|c|c|c|}
\hline Lokasi & Spesies & Jumlah & $\mathrm{Pi}$ & In $\mathrm{Pi}$ & Pi.In P & $\sum$ pi $\ln P$ & $\mathrm{H}^{\prime}$ \\
\hline \multirow{3}{*}{ Arbes (Hulu) } & 1.Pupina bilobata & 35 & 0.686 & -0.376 & -0.257 & \multirow{2}{*}{-0.62} & \multirow{2}{*}{0.62} \\
\hline & 2.Ena montana & 16 & 0.313 & -1.161 & -0.363 & & \\
\hline & Total & 51 & & & & & \\
\hline \multirow{3}{*}{ Wara (Tengah) } & 1.Pupina bilobata & 24 & 0.050 & -2.995 & -0.149 & \multirow{3}{*}{-0.198} & \multirow{3}{*}{0.198} \\
\hline & 2.Ena montana & 451 & 0.949 & -0.052 & -0.049 & & \\
\hline & Total & 475 & & & & & \\
\hline \multirow{3}{*}{ Galala (Hilir) } & 1.Pupina bilobata & 2 & 0.001 & -6.907 & -0.006 & \multirow{3}{*}{-0.007} & \multirow{3}{*}{0.007} \\
\hline & 2.Ena montana & 1.519 & 0.998 & -0.002 & -0.001 & & \\
\hline & Total & 1.521 & & & & & \\
\hline
\end{tabular}

Selain Gastropoda juga ditemukan beberapa makrobentos lain diantaranya adalah yang tertera dalam tabel berikut 
Tabel 7. Famili Makrobentos yang ada pada Seluruh Stasiun Sungai Arbes Batu Merah Ambon

\begin{tabular}{|c|c|c|c|c|c|c|c|}
\hline \multirow[b]{2}{*}{ Titik } & \multirow[b]{2}{*}{ Plot } & \multicolumn{2}{|c|}{ Hulu } & \multicolumn{2}{|c|}{ Tengah } & \multicolumn{2}{|c|}{ Kiri } \\
\hline & & Familly & $\begin{array}{c}\text { Jumlah } \\
\text { Individ } \\
\mathbf{u} \\
\end{array}$ & Spesies & $\begin{array}{l}\text { Jumlah } \\
\text { Individu }\end{array}$ & Familly & $\begin{array}{c}\text { Jumlah } \\
\text { Individu }\end{array}$ \\
\hline \multirow{11}{*}{1} & \multirow{3}{*}{ Kiri } & Corduliidae & 1 & Hirudinidae & 1 & \multirow{3}{*}{$\begin{array}{c}\text { Parathelphu } \\
\text { sidae }\end{array}$} & \multirow{3}{*}{2} \\
\hline & & Tabanidae & 2 & & & & \\
\hline & & Gerridae & 4 & Gerridae & 1 & & \\
\hline & \multirow{4}{*}{ Tengah } & Corduliidae & 1 & \multirow{4}{*}{ Gerridae } & \multirow{4}{*}{1} & \multirow{4}{*}{$\begin{array}{c}\text { Parathelphu } \\
\text { sidae }\end{array}$} & \multirow{4}{*}{1} \\
\hline & & $\begin{array}{c}\text { Hymenosom } \\
\text { athidae }\end{array}$ & 1 & & & & \\
\hline & & Tabanidae & 4 & & & & \\
\hline & & Cirolanidae & 1 & & & & \\
\hline & \multirow{4}{*}{ Kanan } & \multirow{4}{*}{-} & \multirow{4}{*}{ - } & $\begin{array}{c}\text { Parathelphus } \\
\text { idae }\end{array}$ & 1 & \multirow{4}{*}{$\begin{array}{c}\text { Parathelphu } \\
\text { sidae }\end{array}$} & \multirow[b]{4}{*}{1} \\
\hline & & & & & & & \\
\hline & & & & Gerridae & 1 & & \\
\hline & & & & Tabanidae & 1 & & \\
\hline \multirow{4}{*}{2} & \multirow{2}{*}{ kiri } & Tabanidae & 1 & \multirow{2}{*}{ Hirudinidae } & \multirow{2}{*}{2} & \multirow{2}{*}{$\begin{array}{c}\text { Parathelphu } \\
\text { sidae }\end{array}$} & \multirow{2}{*}{2} \\
\hline & & Corixidae & 1 & & & & \\
\hline & tengah & Gerridae & 1 & - & - & $\begin{array}{l}\text { Parathelphu } \\
\text { sidae }\end{array}$ & 2 \\
\hline & kanan & Gerridae & 1 & Hirudinidae & 1 & $\begin{array}{c}\text { Parathelphu } \\
\text { sidae }\end{array}$ & 1 \\
\hline \multirow{6}{*}{3} & \multirow[t]{2}{*}{ kiri } & Corduliidae & 1 & $\begin{array}{c}\text { Larva } \\
\text { tricoptera }\end{array}$ & 1 & \multirow{2}{*}{$\begin{array}{c}\text { Parathelphu } \\
\text { sidae }\end{array}$} & \multirow[t]{2}{*}{1} \\
\hline & & Tabanidae & 1 & Gerridae & 1 & & \\
\hline & tengah & $\begin{array}{c}\text { Larva } \\
\text { tricoptera }\end{array}$ & 1 & $\begin{array}{c}\text { Larva } \\
\text { tricoptera }\end{array}$ & 4 & $\begin{array}{l}\text { Parathelphu } \\
\text { sidae }\end{array}$ & 1 \\
\hline & & Corduliidae & 1 & Hirudinidae & 1 & \multirow{3}{*}{$\begin{array}{c}\text { Parathelphu } \\
\text { sidae }\end{array}$} & \multirow{3}{*}{1} \\
\hline & kanan & Gerridae & 1 & Gerridae & 1 & & \\
\hline & & & & Hirudinidae & 12 & & \\
\hline & & Total spesies & 23 & & 19 & & 12 \\
\hline
\end{tabular}

Penghitungan nilai Familli Biotik Indeks hanya mencakup 4 familly yaitu Cordullidae, Gerridae, Hirudinidae, Tricoptera. Dimana hanya keempat family tersebut yang tergolong dalam makroinvertebrata indikator yang sensitif terhadap polutan. Nilai FBI menunjukkan kondisi perairan pada stasiun 1 tergolong sangat baik. Begitu pula dengan kondisi perairan pada stasiun II dimana nilai FBI diantara 0-3.75 yang berarti 
sangat baik. Hasil perhitungan family biotik indeks pada seluruh stasiun dapat dilihat pada tabel berikut:

Tabel 8. Nilai Famili Biotik Indeks (FBI) pada Seluruh Stasiun Pengamatan

\begin{tabular}{|c|c|c|c|c|c|c|}
\hline No. & Stasiun & Family & $\begin{array}{c}\text { Jumlah } \\
\text { (Xi) }\end{array}$ & $\begin{array}{l}\text { Toleransi } \\
\text { (ti) }\end{array}$ & $\mathbf{X i} \mathbf{i t i}^{\mathrm{t}}$ & \\
\hline \multirow[t]{2}{*}{1.} & \multirow[t]{2}{*}{ I } & Cordullidae & 4 & 4 & \multirow[b]{2}{*}{2,21} & \multirow{2}{*}{ Sangat baik } \\
\hline & & Gerridae & 7 & 7 & & \\
\hline \multirow[t]{3}{*}{2.} & \multirow[t]{3}{*}{ II } & Gerridae & 5 & 5 & \multirow{3}{*}{3,57} & \multirow{4}{*}{ Sangat baik } \\
\hline & & Hirudinidae & 7 & 5 & & \\
\hline & & Tricoptera & 4 & 2 & & \\
\hline \multicolumn{3}{|c|}{ Jumlah } & 27 & & & \\
\hline
\end{tabular}

Berdasarkan kajian ekologis pada hewan-hewan yang menempati aliran sungai arbes baik pada badan maupun sekitar DAS menunjukkan bahwa sungai ini mulai tercemar oleh kegiatan masyarakat yang tinggal disekitarnya. Nilai family biotic spesies yang sensitive terhadap pencemaran menunjukkan kondisi sungai masih dalam kondisi baik pada bagian hulu dan tengah. Akan tetapi kondisi yang berbeda ditemukan pada hilir sungai, dimana keanekaragaman makrobentos dan gastropoda yang ada jumlahnya semakin menurun. Hal ini menunjukkan adanya perubahan kondisi sungai. Keanekaragaman hayati merupakan ukuran kestabilan suatu ekosistem, makin beranekaragaman jenis kehidupan dalam suatua habitat atau makin banyak populasi penyusun suatu komunitas, maka semakin stabil suatu ekosistem (Rachmaati, 2017)

Hasil pengamatan lingkungan sekitar daerah aliran sungai banyak ditemui pembuangan limbah domestik. Selain itu, tata guna lahan diwilayah daerah aliran sungai sudah tidak alami. Banyak terdapat pemukiman dan pembukaan lahan untuk perkebunan disepanjang aliran sungai arbes. Pemukiman memberikan kontribusi limbah domestik berupa sampah dan limbah detergen yang dibuang langsung ke badan sungai. Sedangkan perkebunan memberikan kontribusi berupa limbah pestisida yang terbawa aliran air menuju ke badan sungai.

Kondisi pencemaran yang terjadi di sungai Arbes dapat terlihat dari kondisi fisik yaitu, pada hulu walaupun airnya masih jernih namun masih terlihat buangan sampah deterjen dan banyaknya pengunjung yang buang air sembarangan. Pada bagian hilir airnya sedikit keruh dengan bau yang sedikit menyengat di karenakan adanya pembuangan sampah domestik, limbah organik dan anorganik, kemudian adanya perkebunan yang memungkinkan pestisida mengalir ke badan sungai, dan feses ternak yang di pelihara masyarakat sekitar yang langsung mengalir ke badan sungai. Dan pada bagian hilir airnya sedikit berbau, dan agak berminyak di karenakan padatnya penduduk sekitar yang menempati sekitar sungai sehingga pembuangan sampah lebih mudah. Sumber pencemaran di stasiun III berasal dari limbah domestik, yaitu berupa air buagan

BIOLOGI SEL (VOL 7 NO 1 EDISI JAN-JUL 2018 ISSN 2252-858X/E-ISSN 2541-1225) PAGE 20 
dari kamar mandi dan dapur yang di alirkan langsung ke sungai, dan banyaknya limbah organik dan anorganik yang juga di buang langsung oleh masyarakat.

Dampak dari sungai yang tercemar pada manusia yaitu, limbah organik dan anorganik yang di buang oleh masyarakat ke sungai dapat mengakibatkan gangguan kesehatan, terutama bila di dalam limbah padat tersebut terdapat mikroorganisme pathogen ataupun bahan berbahaya dan beracun. Kemudian buang air besar di sungai dapat menimbulkan penyakit karena tinja merupakan faktor pembawa berbagai macam penyakit bagi manusia karena terdapat mikroorganisme pathogen yang dapat menularkan berbagai penyakit bila masuk ke tubuh manusia (Nela Ambarukmi dkk,---).

Terganggunya kondisi sungai Arbes juga ditandai dengan nilai keanekaragaman capung yang hidup disekitarnya berada pada kondisi sedang hingga rendah. Capung juga dapat disebut sebagai indikator air bersih. Artinya, capung dapat dimanfaatkan untuk memantau kualitas air disekitar lingkungan hidup, karena nimfa capung tidak akan dapat hidup di air yang sudah tercemar atau di perairan yang tidak ada tumbuhannya. Jadi, kehadiran capung dapat menandakan bahwa perairan tersebut masih bersih.

\section{KESIMPULAN}

1. Di kawasan DAS sungai Air Besar Batu Merah Ambon, ditemukan 5 spesies capung jarum yang tergolong dalam 3 family capung jarum (Zygoptera) dan total jumlah individu pada ketiga stasiun yaitu 51 individu.

2. Ditemukan dua spesies gastropoda yaitu Pupina bilobata dan Ena Montana. Penghitungan nilai Familli Biotik Indeks hanya mencakup 4 familly yaitu Cordullidae, Gerridae, Hirudinidae, Tricoptera. Dimana hanya keempat family tersebut yang tergolong dalam makroinvertebrata indikator yang sensitif terhadap polutan.

3. Nilai FBI menunjukkan kondisi perairan pada stasiun 1 tergolong sangat baik. Begitu pula dengan kondisi perairan pada stasiun II dimana nilai FBI diantara 0-3.75 yang berarti sangat baik.

\section{SARAN}

Sungai Arbes merupakan sumber baku air minum masyarakat yang bermukim di sekitar aliran sungai. Banyaknya aktivitas masyarakat yang menggunakan sungai Arbes untuk keperluan domestik, mengakibatkan menurunnya kualitas sungai tersebut. Dengan menggunakan makrobentik, serangga capung, dan gastropoda sebagai bioindikator pencemaran, maka masyarakat dapat mengetahui bahwa air sungai tersebut tercemar. Olehnya itu, perlu adanya sosialisasi kepada masyarakat di sekitar DAS tentang pentingnya capung, hewan makrobentik, dan gastropoda sebagai salah satu indikator pencemaran air sungai.

BIOLOGI SEL (VOL 7 NO 1 EDISI JAN-JUL 2018 ISSN 2252-858X/E-ISSN 2541-1225) PAGE 21 


\section{DAFTAR PUSTAKA}

Anonim. Metode Penelitian. (online, 17 september 2014)

Chay Asdak. 2010. Hidrologi dan Pengelolaan Daerah Aliran Sungai. Yogyakarta: Gadjah Mada Universitity Press.

Leobis, dkk, dalam Herdina Putra, 2013, Komunitas Makrozoobenthos Di Sungai Batang Ombilin Sumatera Barat. (Skripsi).

Nela Ambarukmi, dkk, Identifikasi Makrobenthos Sebagai Bioindikator Pencemaran Air Di Daerah Aliran Air Sungai Bedadung. Hlm 3.

Rachmawati, 2011, Indeks Keanekaragaman Makrozoobenthos Sebagai Bioindikator Tingkat Pencemaran Di Muara Sungai Janeberang. Hlm 107.

Robert dan Soemadiharga, 1982. Shallow Marine Mollusca of North West Java Indonesia. LON-LIPI, Jakarta

Sri Suharmi Siwi. 1991. Kunci Determinasi Serangga. Yogyakarta: Penerbit Kanisius.

Suryono, dalam Berrnadetha Yuswinda Ayu Septiani, dkk. Keanekaragaman Jenis Makrozoobenthos sebagai Penentu Kualitas Air sungai Mruwe Yogyakarta.

Watson dalam Silvy Olivia Hanum, Siti Salmah dan Dahelmi. 2013. Jenis-Jenis Capung (Odonata) di Kawasan Taman Satwa Kandi Kota Sawahlunto Sumatera Barat. Jurnal: Biologi Universitas Andalas 2013, hlm-1 